\title{
Number of bidders and the winner's curse
}

\author{
Citation for published version (APA):
}

Peeters, R., \& Tenev, A. (2016). Number of bidders and the winner's curse. Maastricht University, Graduate School of Business and Economics. GSBE Research Memoranda No. 031 https://doi.org/10.26481/umagsb.2016031

Document status and date:

Published: 01/01/2016

DOI:

10.26481/umagsb.2016031

\section{Please check the document version of this publication:}

- A submitted manuscript is the version of the article upon submission and before peer-review. There can be important differences between the submitted version and the official published version of record.

People interested in the research are advised to contact the author for the final version of the publication, or visit the DOI to the publisher's website.

- The final author version and the galley proof are versions of the publication after peer review.

- The final published version features the final layout of the paper including the volume, issue and page numbers.

Link to publication

\footnotetext{
General rights rights.

- You may freely distribute the URL identifying the publication in the public portal. please follow below link for the End User Agreement:

www.umlib.nl/taverne-license

Take down policy

If you believe that this document breaches copyright please contact us at:

repository@maastrichtuniversity.nl

providing details and we will investigate your claim.
}

Copyright and moral rights for the publications made accessible in the public portal are retained by the authors and/or other copyright owners and it is a condition of accessing publications that users recognise and abide by the legal requirements associated with these

- Users may download and print one copy of any publication from the public portal for the purpose of private study or research.

- You may not further distribute the material or use it for any profit-making activity or commercial gain

If the publication is distributed under the terms of Article $25 \mathrm{fa}$ of the Dutch Copyright Act, indicated by the "Taverne" license above, 


\section{Maastricht University}

Ronald Peeters, Anastas P. Tenev

Number of bidders and the winner's curse

RM/16/031

\section{GSBE}

Maastricht University School of Business and Economics

Graduate School of Business and Economics

P.O Box 616

NL-6200 MD Maastricht

The Netherlands 


\title{
Number of bidders and the winner's curse
}

\author{
Ronald Peeters* Anastas P. Tenev ${ }^{\dagger}$
}

October 20, 2016

\begin{abstract}
The second-price sealed-bid common-value auction exhibits lower winner's curse probability compared to the first-price auction for any number of bidders. For both auction types, above a certain threshold adding more bidders increases the chances of the winner's curse only marginally while it decreases potential losses to the bidders and increases revenue. Below this threshold, having fewer bidders lowers the winner's curse probability and the losses to the bidders, but also the average revenue.
\end{abstract}

JEL classification codes: D44, D82, H57.

Keywords: Winner's curse; number of bidders; common value auctions.

\section{Introduction}

Popular intuition suggests that more bidders participating in a common-value auction should increase the probability of the adverse selection problem referred to as "winner's curse" since this increases the winner's overestimating problem and induces more aggressive bidding. However, due to the imperfect information in common-value auctions, one also deliberately tries not to overbid, especially with fiercer competition. Therefore, the number of active bidders is an instrumental variable in the auction design, one which significantly affects the outcome. It is important that policy-makers understand this when they implicitly restrict the number of bidders in an auction, for instance by selling a product that only a couple of well-known incumbents can afford or in the opposite case when auction entry is highly encouraged. The results in this paper suggest that under certain conditions both can be justified.

The relationship between the winner's curse and the number of bidders in common-value auctions is not explored in great detail in the literature. Investigating real life auction data, Capen et al. (1971) suggest that bidders should have shaded their bids much more in first-price common-value auctions with more participants. Experimental literature supports the claim that the winner's curse increases with the number of bidders and the profits for the winners decrease (cf. Kagel and Levin, 1986; Kagel and Dyer, 1988; Dyer et al., 1989). Kagel et al.

\footnotetext{
${ }^{*}$ Department of Economics, Maastricht University. E-mail: r.peeters@maastrichtuniversity.nl
}

${ }^{\dagger}$ Department of Economics, Maastricht University. E-mail: ap.tenev@maastrichtuniversity.nl 
(1989) suggest that even experienced bidders cannot significantly mitigate the probability of being struck by the winner's curse.

In this paper the effects of changing the number of active bidders in sealed-bid pure common-value auctions are examined in a simplified setting with symmetric linear bidding strategies by means of simulations. The number of bidders is shown to be a key factor affecting not only the probability of occurrence of the winner's curse but also the relative gains or losses of the winner. While being revenue equivalent to the first-price auction the second-price auction is found to lead to a lower probability of the winner's curse irrespective of the number of bidders.

\section{Model and equilibrium}

There are $n$ risk neutral active bidders, all of whom receive i.i.d. initial signals $v_{i}$ drawn from a standard uniform distribution, i.e. $v_{i} \sim U[0 ; 1]$. While these are the bidders' best estimates, full information of the common value is only known ex post. The common value $v_{c}$ is defined as the signal-average of all bidders:

$$
v_{c}=\frac{1}{n} \sum_{i=1}^{n} v_{i} .
$$

The unique symmetric linear equilibrium bidding functions for the first- and the second-price sealed-bid common-value auctions in this setup are given in Klemperer (1999; p.257-259), derived using revenue equivalence: ${ }^{1}$

Proposition 1. (i) The unique symmetric linear equilibrium bidding function for the firstprice sealed-bid common-value auction is given by

$$
b_{i}^{*}=\frac{(n-1)(n+2)}{2 n^{2}} v_{i} .
$$

(ii) The unique symmetric linear equilibrium bidding function for the second-price sealed-bid common-value auction is given by

$$
b_{i}^{*}=\frac{n+2}{2 n} v_{i} .
$$

\section{Impact of number of bidders on auction performance}

The probability that the winner is cursed in the first-price (second-price) auction equals the probability that the highest (second-highest) bid is above the average of all private signals. Deriving this probability boils down to computing the volume of a polytope, that is described by a union of systems of inequalities, based on the bidding functions in Equation (1) or (2). It is possible to estimate this probability for the first- and second-price auction for low number

\footnotetext{
${ }^{1}$ This model meets all conditions for revenue equivalence enumerated in Proposition 3.1 of Krishna (2002).
} 
of bidders, when the dimensions of the polytope are low. However, computing the volume of a polytope is "\#P-hard ..., and a simple task only for low dimensions." (Peña et al., 2016). For this reason simulations were used to approximate it.

For each auction format the interesting performance values (winner's curse, conditional gains and losses, and revenue) were estimated for all numbers of bidders between 2 and 30 and some additional salient numbers till 1000. For each parameter configuration (given by auction format and number of bidders), these values were computed by averaging the outcomes of 10 separate simulation rounds with $10^{6}$ iterations each, where in each iteration new private signals were drawn.

\subsection{Winner's curse}

Figure 1 shows the probability for the winner's curse to occur, (i.e. the winner ending with a net loss), for various numbers of bidders, for the first- and second-price auction formats. The following result summarizes all findings.

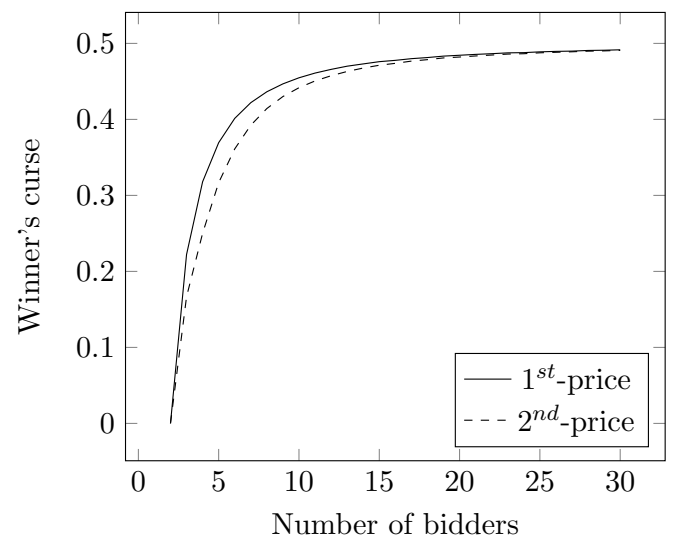

Figure 1: Incidence of the winner's curse as a function of the number of bidders.

Result 1. (i) The probability of the winner's curse is monotonically increasing in the number of bidders (and converging to $\frac{1}{2}$ ) for both auction formats. ${ }^{2}$

(ii) The second-price auction is less prone to the winner's curse for any number of bidders greater than or equal to three.

Clearly, a strategy that prescribes sufficient shading will inadvertently prevent the winner's curse from occurring, because if all bids are lower than the (expected) average of all signals, there will be no winner's curse. Vice versa, any strategy which induces bids higher than the (expected) average of all signals will open the door to the winner's curse. This is partly what happens in the limit with $b^{*} \rightarrow \frac{1}{2} v$. The unwillingness to suffer from the winner's curse and the desire to win balance each other out. The winning bid comes ever closer to the

\footnotetext{
${ }^{2}$ The convergence to $\frac{1}{2}$ can be shown analytically for first-price auctions.
} 
common value and the difference between them could go either way, hence the winner's curse probability of $\frac{1}{2}$ in the limit.

Equations (1) and (2) indicate more competitive bidding in the second-price auction relative to the first-price auction. In spite of this, according to Result 1(ii), the second-price auction reduces the occurrence of a winner's curse. Hence, the effect of the winner paying a price equal to the second-highest bid instead of his winning bid dominates the direct effect of more aggressive bidding.

\subsection{Gains and losses}

Figure 2 presents the average gains by the winning bidder in case of no winner's curse and the average loss for a cursed winner. While Figure 1 focused on the winner's curse occurring or not, the figure below highlights the size of the potential gain (loss) conditional on there being a gain (loss).
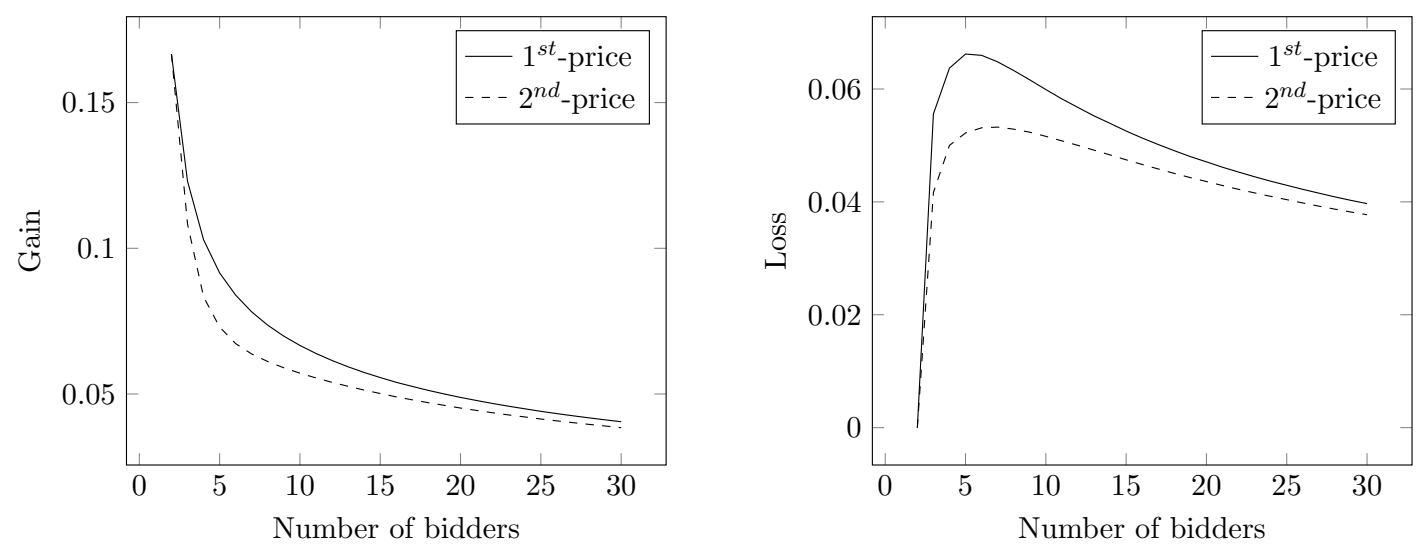

Figure 2: Average gain (loss) in case of absence (occurrence) of winner's curse as a function of the number of bidders in the left (right) panel.

The left panel shows that the surplus of the winner (in case it is positive) decreases sharply up to about $5-10$ bidders and the drop in this range is larger for the second-price auction format. The negative surplus of the winner in case of a winner's curse increases up to 5-6 bidders and gradually decreases afterwards (right panel). Moreover, compared to the gains, the losses are twice smaller in magnitude at their highest point.

Result 2. (i) The average gain of the winning bidder in cases with no winner's curse monotonically decreases as a function of the number of active bidders (and converges to 0).

(ii) The average loss in case of a winner's curse exhibits a maximum between 5 and 6 bidders and a gradual decrease afterwards (and convergence to 0).

(iii) The second-price auction has lower losses, but also lower gains, for any number of bidders greater than or equal to three.

Between 2 and about 5-6 bidders adding more participants to the auction results in much greater losses and palpably lower gains. For larger number of bidders, adding more partici- 
pants will unambiguously decrease both gains and losses (conditional on them occurring). If there are fewer than 6 bidders, further decreasing the number is in favour of the (remaining) bidders. First, their losses decrease in two ways: both the loss in case of a winner's curse and the incidence of the winner's curse decrease. Second, the average gain in case of a gain increases and the probability of a winner's curse decreases. If there are more than 6 bidders, adding more bidders undoubtedly decreases the bidders' potential gains while the effect on the losses is less clear: the loss in case of a winner's curse decreases, but at the same time the probability of a loss increases. Nevertheless, our simulation output reveals that also expected losses decrease.

\subsection{Revenue}

Figure 3 presents the seller's revenue as a function of the number of bidders and the following result summarizes the findings.

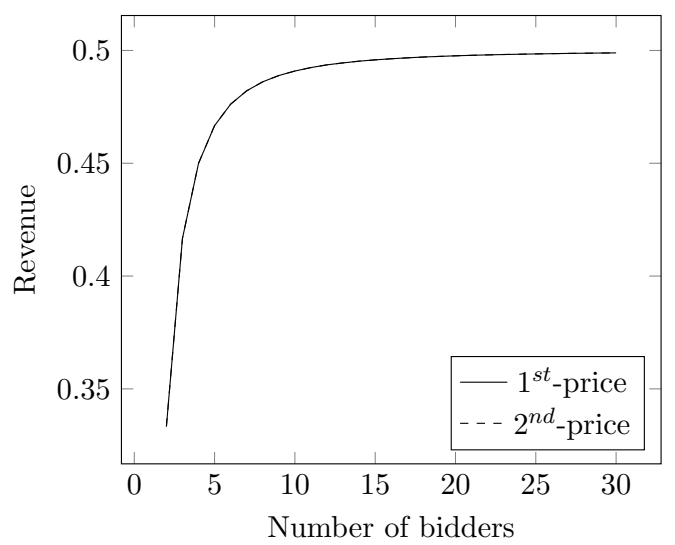

Figure 3: Average revenue as a function of the number of bidders.

Result 3. (i) The average revenue is monotonically increasing in the number of bidders (and converges to $\left.\frac{1}{2}\right)$.

(ii) Both auction formats yield the same revenue. ${ }^{3}$

The first part of this result is a consequence of the first part of Result 1. Since competition increases the chances of overbidding (and it has already been shown in Figure 1 that the winner's curse probability goes up), the increase in revenue for the auctioneer is a logical consequence.

\section{Summary and conclusion}

The first takeaway from this investigation is that the second-price auction format has a bigger chance of mitigating the winner's curse and hence is the better alternative for auctioneers concerned about not having their winning bidders regret they have participated in the auction.

\footnotetext{
${ }^{3}$ Recall Footnote 1.
} 
Concerning the number of bidders, the results indicate a trade-off between the (private) interests of the bidders and the (public) interest of the auctioneer. With relatively many bidders (in this model more than 6), further increasing competition will increase the chance of a winner's curse and lower the expected loss in case it happens while the auctioneer will enjoy a higher revenue, although these effects are rather marginal.

With only a few bidders (in this model fewer than 6) it is more desirable for the bidders that there are even fewer of them, because then they would enjoy lower winner's curse probability and relative losses if they are cursed or in the alternative case they would have much higher gains. However, this is coupled with lower revenue for the auctioneer. Unlike the previous scenario, implicitly or explicitly stimulating a higher number of active bidders here is equivalent to exposing the winners to much higher risk of serious harm which should be a warning sign for auction designers. For example, despite the higher expected revenue, if a government does not want to scare off potential investors with a record of bankruptcies in a specific industry or have to increase its bail-out budget, this effect must be taken into consideration.

\section{References}

Capen EC, RV Clapp and WM Campbell (1971). Competitive bidding in high-risk situations. Journal of Petroleum Technology 23(06): 641-653.

Dyer D, JH Kagel and D Levin (1989). A comparison of naive and experienced bidders in common value offer auctions: A laboratory analysis. The Economic Journal 99(394): 108-115.

Kagel JH and D Dyer (1988). Learning in common value auctions. In: R Tietz, W Albers and R Selten (eds). Bounded Rational Behavior in Experimental Games and Markets: Proceedings of the Fourth Conference on Experimental Economics. Springer Berlin Heidelberg pp.184-197.

Kagel JH and D Levin (1986). The winner's curse and public information in common value auctions. The American Economic Review 76(5): 894-920.

Kagel JH, D Levin, RC Battalio and DJ Meyer (1989). First-price common value auctions: Bidder behavior and the winner's curse. Economic Inquiry 27(2): 241-258.

Klemperer P (1999). Auction theory: A guide to the literature. Journal of Economic Surveys 13(3): 227-286.

Krishna V (2001). Auction Theory. Academic Press, San Diego, CA.

Peña J, B Wu and A Traulsen (2016). Ordering structured populations in multiplayer cooperation games. Journal of the Royal Society Interface 13(114): 1-8. 